\title{
Practice across borders
}

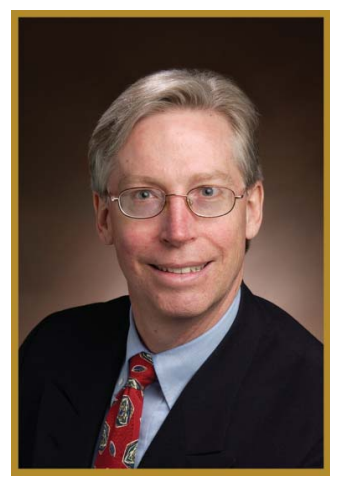

$\mathrm{I}$

$\mathrm{n}$ an effort to understand differences in neurologic practice around the world, and reach out to the international neurology community, Neurology: Clinical Practice will feature a series of articles—starting with the December 2012 issue-investigating how clinical practitioners in different parts of the world approach a patient with a particular neurologic presentation. The goal of the series is to elucidate diagnostic and therapeutic differences and why they exist, with an eye toward engendering a greater understanding of the challenges facing our colleagues in clinical practice.

For the most part, no real research will be required as the information should be drawn from the practitioner's day-to-day practice. If a resident asked, "How would you approach the management of a patient presenting with...," how would you answer him or her?

We will present bylined commentaries by experts from 3 to 5 countries per topic. As a point of comparison, the United States' common approach will be included, either as one of the commentaries or in an accompanying Note. (We recognize that in some instances there may be more diversity among rural and urban practitioners than between-country differences, e.g., the approach to a patient with a neurologic disorder in British Columbia may differ from the approach to that same patient living in Toronto.)

We will ask each commentary author to address the following question: What is the standard approach to this particular neurologic ailment in your country and what affects this standard approach?

Each series will be curated by an expert in the topic field. The expert will suggest potential international authors and serve as one of the reviewers for each commentary submission. In addition, the expert will write the commentary from his or her own country's perspective. Some experts will have practiced neurology in more than one country. We will ask that they focus on their experience in one setting and use their broad experience to frame and inform their discussion.

Currently in the works are series on "Assessment of an unprovoked seizure in an adult" and "Therapeutic strategies for a newly diagnosed patient with Parkinson 
disease." We look forward to your input on future topics and, as always, welcome your participation as authors.

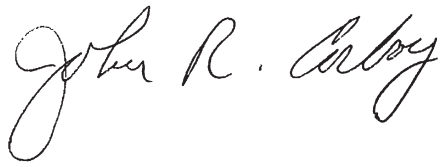

John R. Corboy, MD, FAAN

\section{Download Neurology ${ }^{\circledR}$ Clinical Practice for the} $\mathrm{iPad}^{\circledR}$

The same information so critical to your practice is now brought to you on the $\mathrm{iPad}^{\circledR}$. This dynamic app optimizes the best in digital technology to enhance the reading experience with article-sharing features, multimedia, links, and more.

\section{Enjoy the benefits:}

- Easy-to-read articles you can share via email and social media

- Adjustable text sizing with "pinch and zoom" technology

- Engaging multimedia videos, images, and data supplements

- Ability to store downloaded issues

- Convenient notification when a new issue is available 


\title{
Neurology ${ }^{\circ}$ Clinical Practice
}

Practice across borders

John R. Corboy

Neurol Clin Pract 2012;2;169-170

DOI 10.1212/CPJ.0b013e31826af286

This information is current as of September 17, 2012

\author{
Updated Information \& \\ including high resolution figures, can be found at: \\ Services \\ http://cp.neurology.org/content/2/3/169.full.html \\ Permissions \& Licensing \\ Information about reproducing this article in parts (figures,tables) or in \\ its entirety can be found online at: \\ http://cp.neurology.org/misc/about.xhtml\#permissions \\ Reprints \\ Information about ordering reprints can be found online: \\ http://cp.neurology.org/misc/addir.xhtml\#reprintsus
}

Neurol Clin Pract is an official journal of the American Academy of Neurology. Published continuously since 2011, it is now a bimonthly with 6 issues per year. Copyright Copyright $₫ 2012$ by AAN Enterprises, Inc.. All rights reserved. Print ISSN: 2163-0402. Online ISSN: 2163-0933.

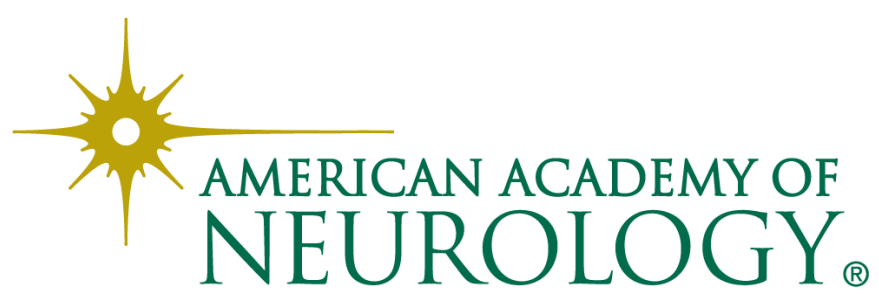

